\title{
Anti-tumor activity of the fermentation broth of Cordyceps militaris cultured in the medium of Radix astragali
}

\author{
Yu-Wei Lin, Been-Huang Chiang * \\ Institute of Food Science and Technology, National Taiwan University, P.O. Box 23-14, Taipei, Taiwan, ROC \\ Received 2 September 2007; received in revised form 25 November 2007; accepted 29 November 2007
}

\begin{abstract}
This study used Radix astragali (RA) as the medium for culturing Cordyceps militaris to investigate the anti-tumor activity of the fermentation broth. It was found that the product from culturing $C$. militaris in RA medium had a better anti-tumor activity than that culturing in synthetic medium. The fermentation broth inhibited the growth of four tumor cells including human gastric cancer AGS cells, human breast cancer MCF-7 cells, human hepatocellular carcinoma Hep G2 cells and murine colorectal adenocarcinoma CT26 cells with IC $50465 \mu \mathrm{g} / \mathrm{mL}, 37 \mu \mathrm{g} / \mathrm{mL}, 25 \mu \mathrm{g} /$ $\mathrm{mL}$, and $20 \mu \mathrm{g} / \mathrm{mL}$, respectively. Although cordycepin was the major bioactive component with the strongest anti-tumor activity in the fermentation broth of $C$. militaris in RA medium, there were other constituents which enhanced the anti-tumor activity of fermentation broth synergistically. To validate the anti-tumor activity, the BALC/c mice were implanted with CT26 cells and then fed with various dosages of the fermentation product. It was found that $20 \mathrm{mg} / \mathrm{kg}$ body weight (BW)/day group had no significant anti-tumor activity as compared to the control group. The dosage of $100 \mathrm{mg} / \mathrm{kg} \mathrm{BW} /$ day and $200 \mathrm{mg} / \mathrm{kg} \mathrm{BW} /$ day group inhibited the tumor volume by $43.81 \%$ and $48.89 \%$. Tumor weight was also reduced by $31.21 \%$ and $39.48 \%$ compared to the control group. Besides, the fermentation broth had low cytotoxicity against primary rat hepatocytes, and did not impose serious side effect on the vital organs of the mice as compared to the chemotherapeutic drug 5-FU.
\end{abstract}

(C) 2007 Elsevier Ltd. All rights reserved.

Keywords: Cordyceps militaris; Radix astragali; Fermentation; Cordycepin; Anti-tumor activity; BALB/c male mice

\section{Introduction}

Cordyceps militaris, a caterpillar-shaped Chinese traditional mushroom, is an entomopathogenic fungus, which belongs to the class Ascomycetes and DongChongXiaCao group in Chinese herbs [1]. Recent studies have pointed out that $C$. militaris has many pharmacological functions such as inhibition of human glomerular mesangical cell proliferation induced by native LDL [2], antifibrotic effect on fibrotic rats induced by BDL/S [3], antiangiogenetic effect [4,5], antiinflammatory [5], improvement of insulin resistance and insulin secretion [6], and growth inhibition of U937 leukemia cells through induction of apoptosis [7]. The major bioactive compound of $C$. militaris is cordycepin which is reported to possess many biological and pharmacological activities such as

\footnotetext{
* Corresponding author. Tel.: +886 2 33664120; fax: +886 223620849 .

E-mail address: bhchiang@ntu.edu.tw (B.-H. Chiang).
}

immunological stimulating, anti-virus, and anti-cancer activities [8-12].

Radix astragali (RA) is the dried root of Astragalus membranaceus Bge. Var. mongholicus and used as a tonic in the traditional Chinese medicine. RA has been used extensively as an adjuvant in cancer treatment and as a phytochemical immune modulator to strengthen the host defense system [1317]. In the last decade, many researchers found that RA can reduce radical-mediated injury to renal tubules [18], protect the inflammation in human amnion [19], induce cell differentiation/death in K562 and HEL cells [20], and activate the cytotoxicity of lymphocytes to increase the secretion of IL-2 and IFN- $\gamma$ [21]. $R$. astragali contains several bioactive constituents such as isoflavonoids, saponins, and polysaccharides [22,23]. The saponins of RA show several therapeutic effects in the progress of diabetic nephropathy [24], prominent IL-2 inducing activity [25], and protective effect against myeloid Graffi tumor [26]. The major isoflavonoid, calycosin, is an active component in $R$. astragali, and it displayed beneficial effects such as anti-tumor activity [27], protection of 
endothelial cells from hypoxia-induced barrier impairment [28], and inhibition of lipid peroxidation by reactive oxygen species [29]. The RA polysaccharides can activate mouse B cells and macrophages [30].

Fermentation is a useful tool for producing biological materials with health promoting properties. The culture medium is very important to the yield of bioactive products because these nutrients are directly related to cell proliferation and metabolite biosynthesis [31-35]. When the carbon and nitrogen sources in the medium are not enough, it might stimulate the microorganisms to go to a different pathway and produce different biosynthesis metabolites. Many investigators have tried to use different medium such as chitosan, wheat bran and bean powder to obtain more bioactive compounds and mycelium [36-38]. Plant oils and fatty acids were used to stimulate the exo-biopolymer production in C. militaris [39]. The $R$. astragali (RA) has been used in the medium for culturing Ganoderma lucidum for producing bioactive polysaccharides during solid-state fermentation [40]. Because both of RA and $C$. militaris possess anti-tumor property, in this study, we used $R$. astragali as the medium to cultivate $C$. militaris and investigate the anti-tumor activity of the fermentation product.

\section{Materials and methods}

\subsection{Microorganism and culture}

The fungal strain used (deposited at the Bioresource Collection and Research Centre, Food Industry Research and Development Institute, Hsinchu, Taiwan) was C. militaris (BCRC 32219). The strain was maintained on potato dextrose agar (PDA) plates at $4{ }^{\circ} \mathrm{C}$ in a refrigerator. Before the experiment, the active PDA slant of the mycelia was prepared by culturing at $25^{\circ} \mathrm{C}$ for 8 days, and then the seed culture was transferred from the active slant grown on PDA medium in a Petri dish at $25^{\circ} \mathrm{C}$ for another 8 days. The inoculant was prepared by punching out $1 \mathrm{~cm}$ of the PDA plate culture with a sterilized cylindrical cutter. Starter flasks $(250 \mathrm{~mL})$ of YM broth were inoculated with mycelia mat (ca. $1 \mathrm{~cm}^{2}$ ) from a stock culture and incubated on a shaker at $175 \mathrm{rpm}$ for 5 days at $25^{\circ} \mathrm{C}$. The starter cultures $(20 \mathrm{~mL})$ were transferred to $500 \mathrm{~mL}$ Erlenmeyer flasks with $200 \mathrm{~mL}$ medium and incubated at $25^{\circ} \mathrm{C}$. For comparison, $C$. militaris was cultured in either RA suspension or synthetic medium. The RA used in this study was Astragalus membranaceus (Fisch.) Bunge. The RA medium contained $20 \mathrm{~g}$ RA powder and $180 \mathrm{~mL}$ water. Synthetic medium was composed of $5 \%$ glucose, $3 \%$ yeast extract, and $0.5 \%$ peptone. After fermentation, the broth was centrifuged at $10,000 \mathrm{rpm}$ for $20 \mathrm{~min}$. The supernatant was filtrated by Whatman no. 1 paper, subjected to freeze-drying, and stored at $-20{ }^{\circ} \mathrm{C}$ in a freezer for further experiments. All fermentation experiments were performed in triplicate to ensure the reproducibility.

\subsection{Cell cultivation and viability assay}

Human gastric cancer AGS cell line, murine colorectal adenocarcinoma CT26 cell line, human hepatocellular carcinoma Hep G2 cell line and human breast cancer MCF-7 cell line were purchased from the Bioresource Collection \& Research Centre (Food Industry Research and Development Institute, Hsinchu, Taiwan). AGS and CT26 cells were cultured in RPMI1640 medium (Gibco, Grand Island, NY). Hep G2 and MCF-7 cells were cultured in DMEM medium (Gibco, Grand Island, NY). All medium were supplemented with 10\% heat-inactivated fetal calf serum (Hyclone, Logan, UT) at $37^{\circ} \mathrm{C}$ in a humidified $5 \% \mathrm{CO}_{2}$ incubator, passaged every 2-3 days with trypsin-EDTA-glucose (TEG) solution $(0.25 \%$ trypsin, $0.1 \%$ EDTA and $0.05 \%$ glucose in Hanks' balanced salt solution), and maintained in exponential growth.
The (3-(4,5-dimethylthiazol-2-yl)-2,5-diphenyltetrazolium bromide, MTT) colorimetric method was used to determine the cell viability. In brief, tumor cells were cultured in a 96-well microplate $\left(10^{5}\right.$ cells per well in $100 \mathrm{~mL}$ medium) for $24 \mathrm{~h}$, and then incubated with different concentrations of sample for $72 \mathrm{~h}$. At the end of incubation, tetrazolium dye was added as an indicator in order to convert tetrazolium salts to a colored product, formazan. The formazan concentration was measured by spectrophotometer at $570 \mathrm{~nm}$.

\subsection{Cytotoxicity test using primary rat hepatocytes}

The primary rat hepatocytes were obtained from anesthetized rats treated with intraperitoneal injection of sodium pentobarbital $(100 \mathrm{mg} / \mathrm{kg}$ body weight). Cell viability was confirmed to be more than $90 \%$ via trypan blue exclusion. After washed, the isolated hepatocytes were resuspended in L-15 cell culture medium ( $\mathrm{pH}$ 7.6) which supplemented with $18 \mathrm{mM}$ HEPES, 2.5\% FBS, $5 \mathrm{mg} / \mathrm{L}$ of insulin, $5 \mathrm{mg} / \mathrm{L}$ of transferrin, $28 \mathrm{mM}$ galactose, $1 \mathrm{M}$ dexamethasone, $100,000 \mathrm{IU} / \mathrm{L}$ penicillin, and $100 \mathrm{mg} / \mathrm{L}$ streptomycin at a density of $5 \times 10^{8}$ cells $/ \mathrm{L}$. Cells $\left(2.5 \times 10^{6}\right)$ were plated on $60 \mathrm{~mm}$ collagenprecoated plastic tissue culture dish (Falcon Labware) and incubated at $37^{\circ} \mathrm{C}$ in a humidified incubator (NUAIRE, USA). After $4 \mathrm{~h}$ plating, the medium was changed by the new medium that contained the same components but replaced FBS with $2.0 \mathrm{~g} / \mathrm{L}$ BSA. After $16 \mathrm{~h}$, medium was renewed and testing sample of various dosages was added. After $24 \mathrm{~h}$, the medium was removed to stop the reaction and cells were washed with phosphate buffered saline. Then cells were removed with a cell scraper for analysis [41].

\subsection{HPLC analysis}

Both of the freeze-dried sample and standard cordycepin (Sigma-Aldrich Co., St. Louis, MO) were dissolved in distilled water before being analyzed by HPLC. The Agilent ZORBAX ODS C18 column $(4.6 \mathrm{~mm} \times 250 \mathrm{~mm}, 5 \mathrm{~mm}$ particle size) was used for separation. The mobile phase was $0.02 \mathrm{M} \mathrm{KH}_{2} \mathrm{PO}_{4}$, which was dissolved in methanol/distilled water (15:85). Elution was performed at a flow rate of $0.7 \mathrm{~mL} / \mathrm{min}$ with column temperature at $25^{\circ} \mathrm{C}$. The UV wavelength of $254 \mathrm{~nm}$ was monitored by a tunable absorbance detector (model: 1100 series, Agilent, USA) [9]. Syringe of $5 \mu \mathrm{L}$ was used for injection. The calibration curve obtained by the standard cordycepin was used for determining the concentration of cordycepin in the sample.

\subsection{Separation and identification of the bioactive constituents in the broth}

The freeze-dried sample was dissolved in distilled water with the concentration of $1000 \mathrm{ppm}$, treated with $90 \%$ (v/v) acetone, and centrifuged for $10 \mathrm{~min}$ at $7000 \mathrm{rpm}$. The precipitate was collected and dried by lyophilization and the filtrate was dried by rotary evaporator. The semi-preparative column (Hypersil HS C18 column, $10 \mathrm{~mm} \times 250 \mathrm{~mm}, 5 \mathrm{~mm}$ particle size) was used for constituent separation. Mobile phase was methanol/distilled water (15:85). Elution was performed at a flow rate of $10 \mathrm{~mL} / \mathrm{min}$ with column temperature $25^{\circ} \mathrm{C}$. The UV wavelength of $254 \mathrm{~nm}$ was monitored by a tunable absorbance detector (model: 1100 series, Agilent, USA) [9]. Syringe of $75 \mu \mathrm{L}$ was used for injection. The eluate was collected and dried by vacuum evaporator for further bioassay. Four fractions were selected and diluted to analyze their anti-tumor activities for CT26 cell line. In proportional to their peak areas (1:1:6:47), fractions were also mixed to test anti-tumor activities for CT 26 cell line of different combinations.

\subsection{Animal model}

BALB/c male mice (6-8 weeks old) were obtained from the National Laboratory Animal Center (Taipei, Taiwan) and housed in a rodent facility at $22 \pm 1{ }^{\circ} \mathrm{C}$ with a 12 -h light/12-h dark cycle. All experiments were performed in accordance with the regulations of the NIH Guide for the Care and Use of Laboratory Animals (DHHS publication No. NIH 85-23, revised 1996). 5Fluorouracil (5-FU) was purchased from Sigma-Aldrich Co. There were six groups of mice in the animal model including normal group, control group, experimental groups $(20 \mathrm{mg} / \mathrm{kg} \mathrm{BW} /$ day, $100 \mathrm{mg} / \mathrm{kg} \mathrm{BW} /$ day and $200 \mathrm{mg} / \mathrm{kg}$ 
BW/day), and the positive control (5-FU) group. Each group had 8 mice. Besides the normal group, mice were implanted with CT26 cells $\left(1 \times 10^{5}\right.$ cells $)$ by subcutaneous injection into the right gluteal region. The normal group and control group received $\mathrm{PBS}\left(\mathrm{NaCl} 8 \mathrm{~g}, \mathrm{KCl} 0.2 \mathrm{~g}, \mathrm{Na}_{2} \mathrm{HPO}_{4} 1.44 \mathrm{~g}\right.$ and $\mathrm{KH}_{2} \mathrm{PO}_{4}$ $0.24 \mathrm{~g}$ dissolved in $1000 \mathrm{~mL}$ distilled water, $\mathrm{pH}$ 7.4) orally with feeding needle everyday. The experimental groups received daily oral injections of sample with $20 \mathrm{mg} / \mathrm{kg} \mathrm{BW} /$ day, $100 \mathrm{mg} / \mathrm{kg} \mathrm{BW} /$ day, and $200 \mathrm{mg} / \mathrm{kg} \mathrm{BW} /$ day. The $5-\mathrm{FU}$ group received intra-peritoneal (i.p.) $15 \mathrm{mg} / \mathrm{kg} \mathrm{BW} /$ day of $5-\mathrm{FU}$ everyday after inoculation.

\subsection{Evaluation of tumor volume, leukocyte count, tumor and visceral organ weight}

The total body weight of each mouse and size of implanted tumors were determined everyday by a single observer. Calipers were used to measure the largest (a) and smallest (b) diameter, and the tumor volume was estimated according to the formula $0.5 a b^{2}$. The leukocyte count was estimated by retroorbital blood sampling every 4 days from the day before mice were injected with CT26 tumor cells. Animals were sacrificed on the 21 days after inoculation. After mice were sacrificed, the tumor and visceral organ weights were measured.

\subsection{Statistical analysis}

All values are means of at least three replicates \pm S.D. Statistical analysis was performed using ANOVA and Duncan test (SAS Institute Inc., Cary, NC, USA) to determine significant differences among means $(p<0.05)$.

\section{Results and discussion}

\subsection{Effect of fermentation temperature on anti-tumor activity}

Using anti-tumor activity as marker, we tested four different fermentation temperatures on four tumor cell lines (AGS, MCF-7, Hep G2, and CT26). It was observed that C. militaris grew successfully at 15,20 and $25^{\circ} \mathrm{C}$. When the culture temperature was $30{ }^{\circ} \mathrm{C}$, the $C$. militaris did not grow well and the broth had little anti-tumor activity. This result agreed with the reports in the literatures that the optimal temperatures for the growth of Cordyceps mycelial and exopolysaccharide production ranged from 20 to $28{ }^{\circ} \mathrm{C}$ [42-44].

The $\mathrm{IC}_{50}$ of the fermentation broth obtained at $25^{\circ} \mathrm{C}$ for AGS, MCF-7, Hep G2, CT26 cell lines were 465.17, 36.9, 24.63, and $20.28 \mu \mathrm{g} / \mathrm{mL}$, respectively (Table 1). Wu et al. used the ethyl acetate extract of Cordyceps sinensis mycelium to

Table 1

Effect of cultivation temperature on $\mathrm{IC}_{50}(\mu \mathrm{g} / \mathrm{mL})$ of Cordyceps militaris fermentation broth for different tumor cell lines

\begin{tabular}{lcccc}
\hline Cell line & \multicolumn{4}{l}{ Temperature $\left({ }^{\circ} \mathrm{C}\right)$} \\
\cline { 2 - 5 } & 15 & 20 & 25 & 30 \\
\hline AGS & $660.61 \pm 56.91^{\mathrm{b}}$ & $698.00 \pm 23.67^{\mathrm{b}}$ & $465.17 \pm 63.29^{\mathrm{a}}$ & $>1000$ \\
MCF-7 & $40.19 \pm 0.47^{\mathrm{b}}$ & $38.32 \pm 0.06^{\mathrm{ab}}$ & $36.90 \pm 3.72^{\mathrm{a}}$ & $>1000$ \\
Hep G2 & $28.44 \pm 2.09^{\mathrm{b}}$ & $28.31 \pm 0.39^{\mathrm{b}}$ & $24.63 \pm 0.77^{\mathrm{a}}$ & $>1000$ \\
CT26 & $25.83 \pm 2.95^{\mathrm{b}}$ & $28.25 \pm 0.56^{\mathrm{c}}$ & $20.28 \pm 2.65^{\mathrm{a}}$ & $>1000$
\end{tabular}

AGS, Human gastric cancer cell line; CT26, murine colorectal adenocarcinoma cell line; Hep G2, human hepatocellular carcinoma cell line; MCF-7, human breast cancer cell line.

${ }^{a}$ Means with different letters $(a-c)$ within a row are significantly different $(p<0.05)$. treat cancer cells, and they found that $\mathrm{IC}_{50}$ for $\mathrm{MCF}-7$ was $44.7 \mu \mathrm{g} / \mathrm{mL}$ [45]. In our study, we used the crude fermentation broth without purification but still observed a similar strength of anti-tumor activity as Wu's research. The best cultivation temperature for $C$. militaris in RA medium appeared to be $25{ }^{\circ} \mathrm{C}$. The fermentation broth cultivated at $25^{\circ} \mathrm{C}$ was also tested on the primary rate hepatocytes to examine its toxicity against normal cells. The $\mathrm{IC}_{50}$ for the primary hepatocytes was $359.85 \pm 17.14 \mu \mathrm{g} / \mathrm{mL}$ as compared to $24.63 \pm 0.77 \mu \mathrm{g} / \mathrm{mL}$ for hepatoma cells, Hep G2. It appeared that the fermentation broth possessed strong anti-tumor activity but was much less toxic to the normal cells. Therefore, it may be a potential remedy for cancer treatment.

The murine colorectal adenocarcinoma CT26 cell line was most susceptible to the $C$. militaris broth. In fact, no matter the C. militaris was cultured at 15,20 , or $25^{\circ} \mathrm{C}$, the anti-tumor activity of the broth for the cancer cells was in the same order of CT26 > Hep G2 > MCF-7 > AGS (Table 1). Since the CT26 was the most sensitive cell line for the $C$. militaris broth, this cell line was used for the subsequent studies.

\subsection{Effect of agitation and cultivation time on CT26 cells}

Many investigations have shown that the aeration and agitation will influence the mycelial morphology of $C$. militaris $[46,47]$. The effect of agitation and cultivation time on the $\mathrm{IC}_{50}$ of $C$. militaris fermentation broth for CT26 cells was shown in Table 2. The anti-tumor activity of the fermentation broth without agitation increased with the cultivation time, and there was a sharp increase in anti-tumor activity from 3 to 4 weeks of cultivation. For the fermentation at 100 rpm, practically no antitumor activity was found in the broth after 2 weeks of cultivation. After 3 weeks of cultivation with agitation, the $\mathrm{IC}_{50}$ of the fermentation broth was approximately $700 \mu \mathrm{g} / \mathrm{mL}$. These results clearly showed that the static culture of $C$. militaris had better anti-tumor activity than the agitated culture. From the morphological observation, the mycelium of $C$. militaris matted together on the surface of medium during static cultivation, and the thickness and area of the mat increased with fermentation time. When the agitation speed was $100 \mathrm{rpm}$, the mycelium formed 2-3 mm pellets suspended in the broth. Masuda et al. [47] also demonstrated that in the shaking culture of $C$. militaris the cordycepin production was suppresses to 1/ 10 (buffled Erlenmeyer flask) $\sim 1 / 3$ (no-buffled) relative to the surface culture, and they suspected that shear stress might have adverse effect on the fungus. Contrarily, Mao et al. [48]

Table 2

Effects of cultivation time and agitation speed on $\mathrm{IC}_{50}(\mu \mathrm{g} / \mathrm{mL})$ of Cordyceps militaris fermentation broth produced at $25^{\circ} \mathrm{C}$ for $\mathrm{CT} 26$ cell line

\begin{tabular}{lllll}
\hline $\begin{array}{l}\text { Agitation } \\
\text { speed }^{\mathrm{a}}\end{array}$ & \multicolumn{4}{l}{ Time } \\
\cline { 2 - 5 } & 1 week & 2 weeks & 3 weeks & 4 weeks \\
\hline $100 \mathrm{rpm}$ & $>1000$ & $>1000$ & $673.31 \pm 75.01^{\mathrm{a}}$ & $689.4 \pm 79.65^{\mathrm{a}}$ \\
$0 \mathrm{rpm}$ & $>1000$ & $516.14 \pm 169.33^{\mathrm{c}}$ & $248.23 \pm 9.08^{\mathrm{b}}$ & $20.28 \pm 2.65^{\mathrm{a}}$ \\
\hline
\end{tabular}

\footnotetext{
${ }^{\mathrm{a}}$ Means with different letters $(\mathrm{a}-\mathrm{c})$ within a row are significantly different $(p<0.05)$.
} 
demonstrated that the maximum cordycepin production was achieved under $110 \mathrm{rpm}$ of agitation. Nevertheless, our study suggested that the optimal cultivation condition for $C$. militaris in RA medium was at $25{ }^{\circ} \mathrm{C}$ for 4 weeks without agitation.

\subsection{Cultivation medium comparison}

Composition of the medium is very important for fermentation. Different medium will stimulate the production of different secondary metabolites and active compounds. Using anti-tumor activity as a marker, we compared the bioactivity of the fermentation broth of $C$. militaris cultured with synthetic medium and RA medium. First of all, we found that the $\mathrm{IC}_{50}$ of RA medium without fermentation was higher than $1000 \mu \mathrm{g} / \mathrm{mL}$, and practically did not have any anti-tumor activity. The $\mathrm{IC}_{50}$ of fermentation broth from RA medium and from synthetic medium for CT26 cell line were $20.28 \mu \mathrm{g} / \mathrm{mL}$ and $43.03 \mu \mathrm{g} / \mathrm{mL}$, respectively (Table 3 ). This result indicated that the fermentation broth of $C$. militaris cultured in RA medium has stronger anti-tumor activity than that in synthetic medium. Cordycepin is commonly recognized as a major antitumor compound of $C$. militaris and usually used as marker during fermentation of $C$. militaris. Yoshikawa et al. [18] demonstrated that orally administered cordycepin $15 \mathrm{mg} / \mathrm{kg}$ BW inhibited melanoma cell growth in mice with no adverse effects. Cordycepin can inhibit cancer cell growth both in vitro and in vivo. In our study, the cordycepin content in RA and synthetic medium were $46.35 \mathrm{ppm}$ and $112.62 \mathrm{ppm}$, respectively (Table 3). It is interesting to note that the fermentation broth from synthetic medium had more cordycepin content (Fig. 1) but less anti-tumor activity than that in RA medium.

\subsection{Constituents analysis}

From previous results, we concluded that cordycepin is not the only compound with anti-tumor activity in the fermentation broth. Because the fermentation broth contained one-fourth of protein, we used $90 \%$ acetone to precipitate protein and evaluated the anti-tumor activity of precipitate and filtrate. It was found that the precipitated protein had no anti-tumor activity, but the anti-tumor activity of the filtrate was significantly increased due to protein removal. The $\mathrm{IC}_{50}$ of filtrate for CT26 was $4.25 \pm 0.86 \mu \mathrm{g} / \mathrm{mL}$ (Table 4), much higher than the crude broth $(20.28 \pm 2.65)$. By using semipreparative column, we successfully separated major anti-

Table 3

Comparison of the cordycepin content and $\mathrm{IC}_{50}(\mu \mathrm{g} / \mathrm{mL})$ for CT26 cells of Cordyceps militaris fermentation broths produced using synthetic medium and RA medium at $25^{\circ} \mathrm{C}$ for 4 weeks without agitation

\begin{tabular}{lll}
\hline $\mathrm{IC}_{50}$ and cordycepin & \\
& \multicolumn{1}{l}{ Medium } & \\
\cline { 2 - 3 } & Synthetic medium & RA medium \\
\hline $\mathrm{IC}_{50}$ for CT $26(\mu \mathrm{g} / \mathrm{mL})$ & $43.03 \pm 3.47^{\mathrm{b}}$ & $20.28 \pm 2.65^{\mathrm{a}}$ \\
Cordycepin content $(\mathrm{ppm})$ & $112.62 \pm 3.9^{\mathrm{b}}$ & $46.35 \pm 0.81^{\mathrm{a}}$
\end{tabular}

\footnotetext{
${ }^{\mathrm{a}}$ Means with different letters ( $\mathrm{a}$ and $\mathrm{b}$ ) within a row are significantly different $(p<0.05)$.
}

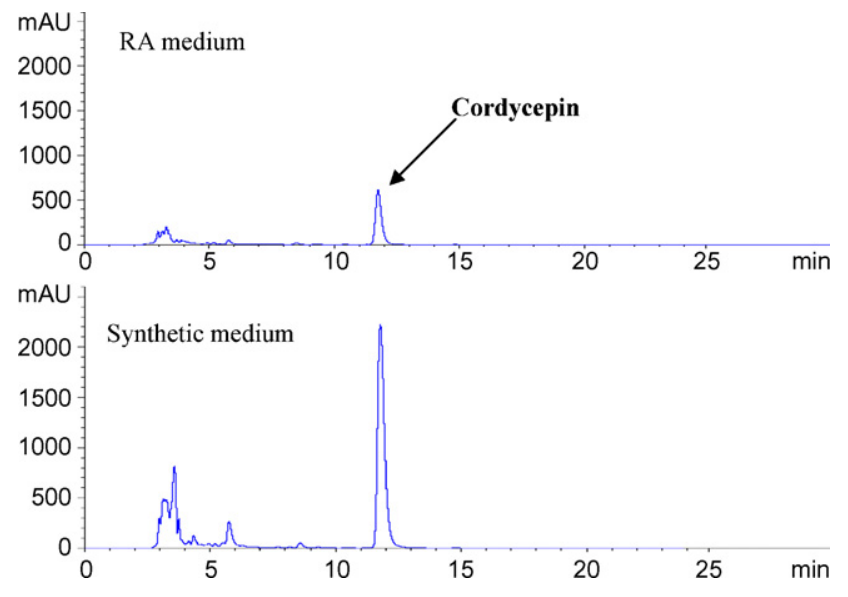

Fig. 1. The HPLC profiles of cordycepin from RA and synthetic mediums. The mediums were fermented by $C$. militaris at $25^{\circ} \mathrm{C}$ for 4 weeks without agitation.

tumor constituents from the filtrate. Four fractions were collected and analyzed for their anti-tumor activities (Fig. 2). Fraction 4 was identified to be cordycepin. The $\mathrm{IC}_{50}$ of fraction 1 to fraction 4 for CT26 were $10.12 \pm 1.69,23.34 \pm 1$, $50.34 \pm 3.77$, and $2.91 \pm 0.17 \mu \mathrm{g} / \mathrm{mL}$, respectively (Table 4). It is worth to note that the combinations of fractions $1+4$ and $2+4$ had significantly higher anti-tumor activity than fraction 4 $(p<0.05)$, the cordycepin. In particular, fraction 2 plus fraction 4 had the strongest anti-tumor activity with $\mathrm{IC}_{50}$ $2.05 \pm 0.15 \mu \mathrm{g} / \mathrm{mL}$, only $70 \%$ of the $\mathrm{IC}_{50}$ value of cordycepin (fraction 4). This result demonstrated that fraction 1 or 2 and fraction 4 had synergistic effect for anti-tumor activity. However, because of the complexity of the constituents found in the fermentation broth, purification and identification of these fractions, and their synergistic effects on anti-tumor activity need to be further investigated.

\subsection{Changes in mice body weight and leukocyte count}

The applied dosages of freeze-dried $C$. militaris broth were $20 \mathrm{mg} / \mathrm{kg} \mathrm{BW} /$ day, $100 \mathrm{mg} / \mathrm{kg} \mathrm{BW} /$ day and $200 \mathrm{mg} / \mathrm{kg} \mathrm{BW/}$ day for the study of anti-tumor activity in vivo. It was found that

Table 4

The $\mathrm{IC}_{50}$ of various fractions of the filtrate of $C$. militaris fermentation broth for CT 26 cells

\begin{tabular}{lc}
\hline Fractions & $\mathrm{IC}_{50}$ for CT26 $(\mu \mathrm{g} / \mathrm{mL})$ \\
\hline Filtrate & $4.25 \pm 0.86$ \\
Fr. 1 & $10.12 \pm 1.69$ \\
Fr. 2 & $23.41 \pm 1.00$ \\
Fr. 3 & $50.34 \pm 3.77$ \\
Fr. 4 & $2.91 \pm 0.17^{\mathrm{c}}$ \\
Fr. $1+2$ & $13.09 \pm 2.31$ \\
Fr. $1+3$ & $35.21 \pm 3.38$ \\
Fr. $2+3$ & $23.44 \pm 2.18$ \\
Fr. $1+4$ & $2.33 \pm 0.04^{\mathrm{b}}$ \\
Fr. $2+4$ & $2.05 \pm 0.15^{\mathrm{a}}$ \\
Fr. $3+4$ & $2.76 \pm 0.16^{\mathrm{c}}$
\end{tabular}

${ }^{\mathrm{a}}$ Means with different letters $(\mathrm{a}-\mathrm{c})$ within a column are significantly different $(p<0.05)$. 


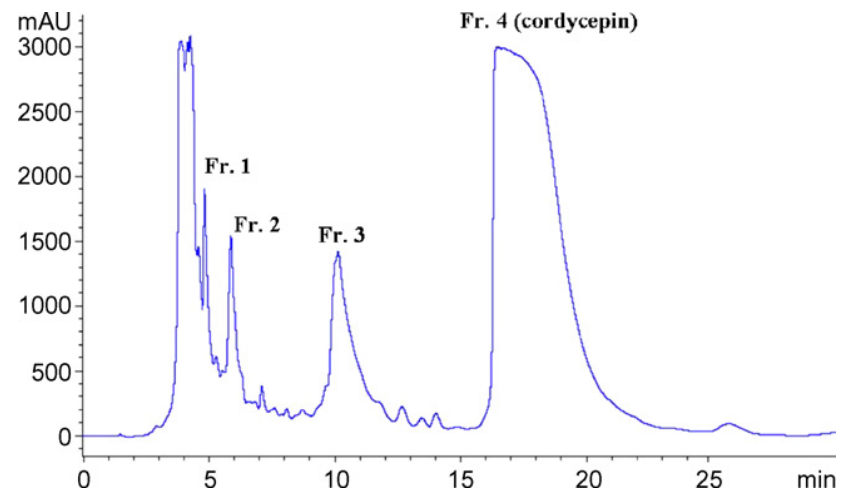

Fig. 2. The chromatogram of the filtrate of $C$. militaris fermentation broth after protein removal by acetone precipitation and separated by semi-preparative HPLC system.

except the positive control group, 5-FU group, there was no significant change in body weight in all treatment groups (Fig. 3). 5-FU is a fluorinated pyrimidine whose metabolites are believed to trigger apoptosis by depleting thymidine. This chemical is commonly used in the treatment of carcinomas of the colon, rectum, stomach, pancreas, breast, head and neck, anus, and gallbladder. The predominant side effects of 5-FU are diarrhea, anorexia, enteritis, hand-foot syndrome, and myelosuppression. After the treatment, mice in the positive control group were more angular than mice in other group, which was the normal side effect of 5-FU. The fact that all of the mice in the treatment groups did not show any loss in body weight suggested that the $C$. militaris broth did not affect the normal metabolism of the animals.

As shown in Fig. 4, the leukocyte count of mice in the positive control group decreased significantly. In other words, mice treated with 5-FU had weaker immune ability. Contrary to the positive control group, the leukocyte counts in other treatment groups increased slightly and there was no significant

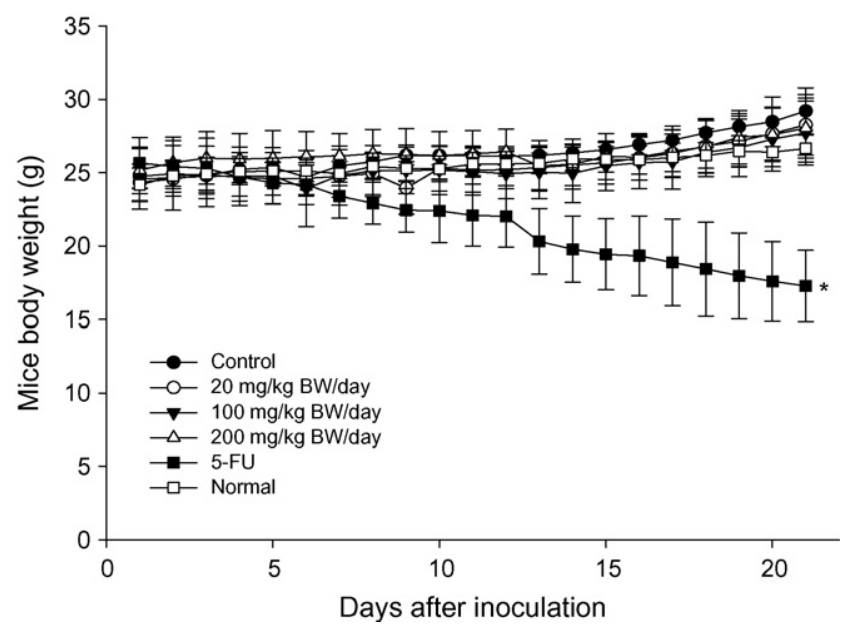

Fig. 3. Changes of body weight of CT26-implanted BALB/c mice administrated with different samples. The mice in 5-FU group were intraperitoneally administrated with $10 \mathrm{mg} / \mathrm{kg} \mathrm{BW} / \mathrm{day}$, and the mice in normal and control groups were orally administrated with PBS. C: Control, $\bigcirc: 20 \mathrm{mg} / \mathrm{kg}$ BW/day, $\boldsymbol{\nabla}: 100 \mathrm{mg} / \mathrm{kg}$ BW/day, $\triangle: 200 \mathrm{mg} / \mathrm{kg}$ BW/day, $\mathbf{\square}: 5-\mathrm{FU}, \square:$ Normal. *Significantly different at $0.05 \%$ level compared with normal group.

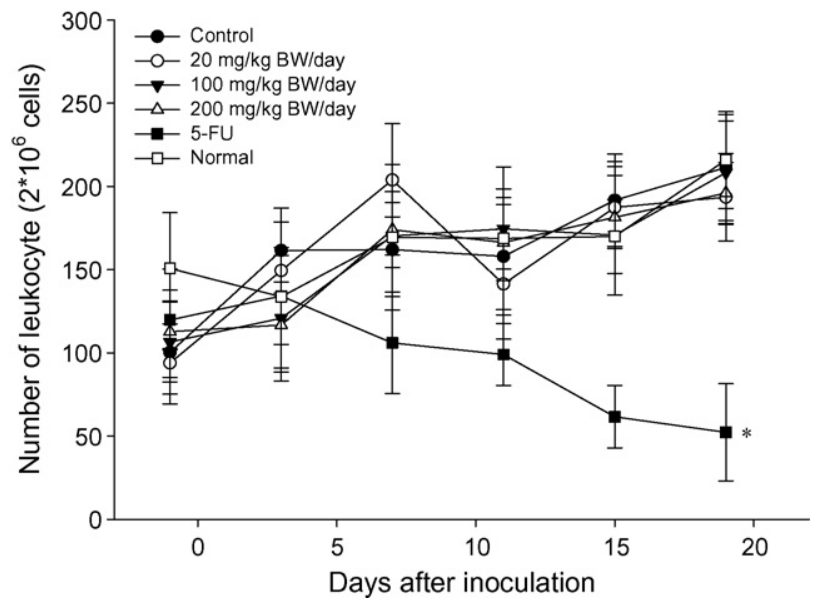

Fig. 4. Changes in leukocyte number of CT26-implanted BALB/c mice administrated with different samples. The mice in 5-FU group were intraperitoneally administrated with $10 \mathrm{mg} / \mathrm{kg} \mathrm{BW} /$ day, and the mice in normal and control groups were orally administrated with PBS. $\bigcirc$ : Control, $\bigcirc: 20 \mathrm{mg} / \mathrm{kg}$ BW/day, $\nabla$ : $100 \mathrm{mg} / \mathrm{kg} \mathrm{BW/day,} \triangle$ : $200 \mathrm{mg} / \mathrm{kg}$ BW/day, $\square: 5-F U, \square$ : Normal. *Significantly different at $0.05 \%$ level compared with normal group.

difference between these groups. This result indicated that the immune system of mice were unaffected by the treatment of $C$. militaris fermentation broth.

\subsection{Inhibition of tumor growth}

As shown in Fig. 5, low-dose treatment (20 mg/kg BW/day) had no significant effect on tumor growth as compared to the PBS control group. However, $100 \mathrm{mg} / \mathrm{kg} \mathrm{BW/day} \mathrm{and} 200 \mathrm{mg} /$ $\mathrm{kg} \mathrm{BW/day} \mathrm{treatments} \mathrm{showed} \mathrm{a} \mathrm{significant} \mathrm{decrease} \mathrm{in} \mathrm{tumor}$ size $(p<0.05)$. There was no significant difference between these two groups. After 21 days of inoculation, the inhibition of tumor size in $100 \mathrm{mg} / \mathrm{kg} \mathrm{BW/day} \mathrm{and} 200 \mathrm{mg} / \mathrm{kg} \mathrm{BW/day}$

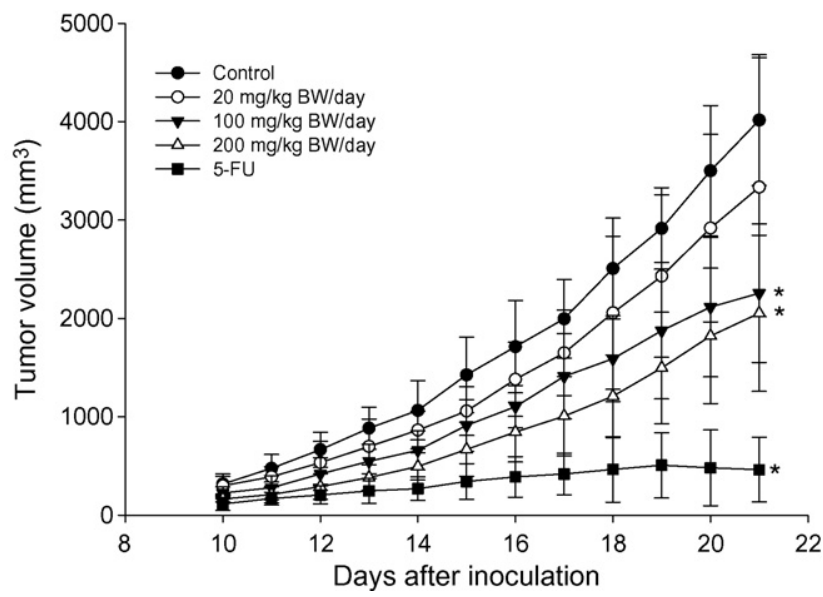

Fig. 5. Changes in tumor volume $\left(\mathrm{mm}^{3}\right)$ of CT26-implanted BALB/c mice administrated with different samples. The mice in 5-FU group were intraperitoneally administrated with $10 \mathrm{mg} / \mathrm{kg} \mathrm{BW} /$ day, and the mice in normal and control groups were orally administrated with PBS. The tumor volume was determined by direct measurement with calipers and calculated by the formula: (length $(\mathrm{mm}) \times$ width $\left.(\mathrm{mm})^{2}\right) / 2$. C : Control, $\bigcirc: 20 \mathrm{mg} / \mathrm{kg} \mathrm{BW} /$ day, $\nabla$ : $100 \mathrm{mg} / \mathrm{kg} \mathrm{BW} /$ day, $\triangle: 200 \mathrm{mg} / \mathrm{kg} \mathrm{BW} /$ day, $\mathbf{\square}:$ 5-FU. *Significantly different at $0.05 \%$ level compared with control group. 
Table 5

Changes of organ weight (g) of CT26-implanted BALB/c mice fed with various amount samples for 21 days

\begin{tabular}{|c|c|c|c|c|c|}
\hline \multirow[t]{2}{*}{ Group } & \multicolumn{5}{|l|}{ Organ $^{a}$} \\
\hline & Heart & Liver & Lung & Kidney & Tumor \\
\hline Normal & $0.158 \pm 0.006^{\mathrm{b}}$ & $1.846 \pm 0.146^{\mathrm{b}}$ & $0.185 \pm 0.022^{\mathrm{b}}$ & $0.479 \pm 0.010^{\mathrm{b}}$ & - \\
\hline Control & $0.145 \pm 0.011^{b}$ & $1.993 \pm 0.224^{\mathrm{b}}$ & $0.209 \pm 0.014^{\mathrm{bc}}$ & $0.488 \pm 0.034^{\mathrm{b}}$ & $5.314 \pm 0.968^{\mathrm{c}}$ \\
\hline $20 \mathrm{mg}$ & $0.148 \pm 0.015^{\mathrm{b}}$ & $1.998 \pm 0.155^{\mathrm{b}}$ & $0.218 \pm 0.023^{c}$ & $0.461 \pm 0.043^{\mathrm{b}}$ & $4.516 \pm 1.026^{\mathrm{c}}$ \\
\hline $100 \mathrm{mg}$ & $0.148 \pm 0.007^{\mathrm{b}}$ & $1.936 \pm 0.174^{\mathrm{b}}$ & $0.219 \pm 0.035^{\mathrm{c}}$ & $0.469 \pm 0.036^{\mathrm{b}}$ & $3.655 \pm 0.813^{b}$ \\
\hline $200 \mathrm{mg}$ & $0.154 \pm 0.023^{b}$ & $1.884 \pm 0.232^{\mathrm{b}}$ & $0.189 \pm 0.022^{b}$ & $0.465 \pm 0.065^{\mathrm{b}}$ & $3.216 \pm 1.153^{b}$ \\
\hline $5-\mathrm{FU}$ & $0.104 \pm 0.022^{\mathrm{a}}$ & $0.981 \pm 0.340^{\mathrm{a}}$ & $0.151 \pm 0.028^{\mathrm{a}}$ & $0.279 \pm 0.055^{\mathrm{a}}$ & $0.744 \pm 0.583^{\mathrm{a}}$ \\
\hline
\end{tabular}

${ }^{\mathrm{a}}$ Means with different letters $(\mathrm{a}-\mathrm{c})$ within a column are significantly different $(p<0.05)$.

groups were $43.81 \%$ and $48.89 \%$, respectively. This result indicated that $C$. militaris broth could effectively inhibit the tumor growth not only in vitro but also in vivo. Wu et al. [45] also found that $12 \mu \mathrm{g} / \mathrm{mL}$ of the ethyl acetate extract of Cordyceps sinensis mycelium could inhibit the proliferation of B16 cancer cell by $50 \%$. When mice were treated with $500 \mathrm{mg} /$ $\mathrm{kg} \mathrm{BW} /$ day of the acetate extract for 27 days, the tumor weight was decreased by $48 \%$; the tumor volume was reduced by $62 \%$. In our study, the fermentation broth itself, without extraction, could achieve similar anti-tumor activity.

\subsection{Changes of tumor and organs weight}

When the mice were sacrificed on the 21 days after inoculation, it was found that the positive group had the minimum tumor weight of $0.744 \mathrm{~g}$ (Table 5). Although there was no significant difference in tumor weight between PBS control group and $20 \mathrm{mg} / \mathrm{kg} \mathrm{BW} /$ day group, when the treatment dosage was increased to 100 and $200 \mathrm{mg} / \mathrm{kg} \mathrm{BW} /$ day, the tumor weight were reduced significantly and the reduction of tumor weight were $31.21 \%$ and $39.48 \%$, respectively. We suspect that further increase of dosage may be able to enhance the anti-tumor effect of the $C$. militaris fermentation broth. Since the weight of all of the vital organs of mice checked in this study were basically unaffected by the treatment, suggesting that the $C$. militaris fermentation broth did not have any serious side effect on mice's organ development. The results reported above demonstrated that the fermentation broth of $C$. militaris cultured in RA medium had strong anti-tumor activity both in vitro and in vivo without significant side effect.

\section{Conclusion}

This study found that using $R$. astragali as the medium could enhance the anti-tumor activity of the fermentation broth of $C$. militaris as compared to the synthetic medium. Although cordycepin is definitely the key compound responsible for the anti-tumor activity of the fermentation broth, there are other unknown compounds also contributing to the anti-tumor activity of the broth synergistically with cordycepin. Therefore, further experiments are needed in order to identify all of the bioactive compounds as well as the possible anti-tumor mechanism.

\section{Acknowledgement}

This research was partially supported by the Microbio Co. Ltd. (Taipei, Taiwan).

\section{References}

[1] Ying J, Mao X, Ma Q, Zong Y, Wen H. Icons of medicinl muchoom from China. Beijing: Science Press; 1987 (in Chinese).

[2] Wu ZL, Wang XX, Cheng WY. Inhibitory effect of Cordyceps sinensis and Cordyceps militaris on human glomerular mesangial cell proliferation induced by native LDL. Cell Biochem Funct 2000;18:93-7.

[3] Nan JX, Park EJ, Yang BK, Song CH, Ko G, Sohn DH. Antifibrotic effect of extracellular biopolymer from submerged mycelial cultures of Cordyceps militaris on liver fibrosis induced by bile duct ligation and scission in rats. Arch Pharm Res 2001;24:327-32.

[4] Yoo HS, Shin JW, Cho JH, Son CG, Lee YW, Park SY, et al. Effects of Cordyceps militaris extract on angiogenesis and tumor growth. Acta Pharmacol Sin 2004;25:657-65.

[5] Won SY, Park EH. Anti-inflammatory and related pharmacological activities of cultured mycelia and fruiting bodies of Cordyceps militaris. J Ethnopharmacol 2005;96:555-61.

[6] Choi SB, Park CH, Choi MK, Jun DW, Park S. Improvement of insulin resistance and insulin secretion by water extracts of Cordyceps militaris, Phellinus linteus, and Paecilomyces tenuipes in 90\% pancreatectomized rats. Biosci Biotechnol Biochem 2004;68:2257-64.

[7] Park C, Hong SH, Lee JY, Kim GY, Choi BT, Lee YT, et al. Growth inhibition of U937 leukemia cells by aqueous extract of Cordyceps militaris through induction of apoptosis. Oncol Rep 2005;13:1211-6.

[8] Cunningham KG, Hutchinson SA, Manson W, Spring FS. Cordycepin, a metabolic product from cultures of Cordyceps militaris (Linn.) Link. Part I. Isolation and characterisation. J Chem Soc 1951;2299-300.

[9] Ahn YJ, Park SJ, Lee SG, Shin SC, Choi DH. Cordycepin: selective growth inhibitor derived from liquid culture of Cordyceps militaris against Clostridium spp. J Agric Food Chem 2000;48:2744-8.

[10] Zhou XX, Meyer CU, Schmidtke P, Zepp F. Effect of cordycepin on interleukin-10 production of human peripheral blood mononuclear cells. Eur J Pharmacol 2002;453:309-17.

[11] De Julian-Ortiz JV, Galvez J, Munoz-Collado C, Garcia-Domenech R, Gimeno-Cardona C. Virtual combinatorial syntheses and computational screening of new potential anti-herpes compounds. J Med Chem 1999;17:3308-14.

[12] Sugar AM, Mccaffrey RP. Antifungal activity of 3 -deoxyadenosine (cordycepin). Antimicrob Agents Chemother 1998;42:1424-7.

[13] Cha RJ, Zeng DW, Chang QS. Non-surgical treatment of small cell lung cancer with chemo-radio-immunotherapy and traditional Chinese medicine. Zhonghua Neike Zazhi 1994;33:462-6.

[14] Li NQ. Clinical and experimental study on shen-qi injection with chemotherapy in the treatment of malignant tumor of digestive tract. Zhongguo Zhongxiyi Jiehe Zazhi 1992;12:588-92. 
[15] Lin J, Dong HF, Oppenheim JJ, Howard OM. Effects of Astragali radix on the growth of different cancer cell lines. World $\mathrm{J}$ Gastroenterol 2003;9:670-3.

[16] Jin R, Kurashige S. Effects of Chinese herbs on macrophage functions in N-butyl-N-butanolnitrosoamine treated mice. Immunopharmacol Immunotoxicol 1996;18:105-14.

[17] Hong CY, Ku J, Wu P. Astragalus membranaceus stimulates human sperm motility in vitro. Am J Chin Med 1992;20:289-94.

[18] Yoshikawa N, Nakamura K, Yamaguchi Y, Kagota S, Shinozuka K, Kunitomo M. Antitumor activity of cordycepin in mice. Clin Exp Pharmacol Physiol 2004;31:S51-3.

[19] Shon YH, Nam KS. Protective effect of Astragali radix extract on interleukin $1 \beta$-induced inflammation in human amnion. Phytother 2003; 17:1016-20.

[20] Cheng XD, Hou CH, Zhang XJ, Xie HY, Zhou WY, Yang L, et al. Effects of Huangqi (Hex) on inducing cell differentiation and cell death in K562 and HEL Cells. Acta Biochim Biophys Sin 2004;36:211-7.

[21] Kurashige S, Akuzawa Y, Endo F. Effects of Astragali radix extract on carcinogenesis, cytokine production, and cytotoxicity in mice treated with a carcinogen, N-butly- $\mathrm{N}^{\prime}$-butanolnitrosoamine. Cancer Invest 1997;17: $30-5$.

[22] Sinclair S. Chinese herbs: a clinical review of Astragalus, Ligusticum, and Schizandrae. Altern Med Rev 1998;3:338-44.

[23] Wagner H, Bauer R, Xiao PG, Chen JM, Michler G. Radix Astragali (Huang Qi). Chinese Drug Monographs and Analysis 1997;1:1-17.

[24] Yin XX, Zhang YD, Wu HW, Zhu X, Zheng XG, Jiang SJ, et al. Protective effects of Astragalus saponin I on early stage of diabetic nephropathy in rats. J Pharmacol Sci 2004;95:256-66.

[25] Yesilada E, Bedir E, Çalış I, Takaishi Y, Ohmoto Y. Effects of triterpene saponins from Astragalus species on in vitro cytokine release. J Ethnopharmacol 2005;96:71-7.

[26] Krasteva IN, Toshkova RA, Nikolov SD. Protective effect of Astragalus corniculatus saponins against myeloid Graffi tumour in hamsters. Phytother 2004;18:255-7.

[27] Kim DH, Yu KU, Bae EA, Han MJ. Metabolism of puerarin and daidzin by human intestinal bacteria and their relation to in vitro cytotoxicity. Biol Pharm Bull 1998;21:628-30.

[28] Fan Y, Wu DZ, Going YQ, Zhou JY, Hu ZB. Effects of calycosin on the impairment of barrier function induced by hypoxia in human umbilical vein endothelial cells. Euro J Pharmacol 2003;481:33-40.

[29] Toda S, Shirataki Y. Inhibitory effects of isoflavones in roots of Astragalus membranaceus Bunge (Astragali Radix) on lipid peroxidation by reactive oxygen species. Phytother Res 1998;12:59-61.

[30] Shao BM, Xu W, Dai H, Tu PF, Li ZG, Gao XM. A study on the immune receptors for polysaccharides from the roots of Astragalus membranaceus, a Chinese medicinal herb. Biochem Biophys Res Commun 2004;20:1103-11.

[31] Tang YJ, Zhong JJ. Fed-batch fermentation of Ganoderma lucidum for hyperproduction of polysaccharide and ganoderic acids. Enzyme Microbial Technol 2002;31:20-8.

[32] Kim SW, Xu CP, Hwang HJ, Choi JW, Kim CW, Yun JW. Production and characterization of exopolysaccharides from an enthomopathogenic fungus Cordyceps militaris NG3. Biotechnol Prog 2003;19:428-35.
[33] Park JP, Kim SW, Hwang HJ, Yun JW. Optimization of submerged culture conditions for the mycelial growth and exo-biopolymer production by Cordyceps militaris. Lett App Microb 2001;33:76-81.

[34] Fang QH, Zhong JJ. Submerged fermentation of higher fungus Ganoderma lucidum for production of valuable bioactive metabolites-ganoderic acid and polysaccharide. Biochem Eng J 2002;10:61-5.

[35] Casas López JL, Sánchez Pérez JA, Fernández Sevilla JM, Acién Fernández FG, Molina Grima E, Chisti Y. Production of lovastatin by Aspergillus terreus: effects of the $\mathrm{C}: \mathrm{N}$ ratio and the principal nutrients on growth and metabolite production. Enzyme Microbial Technol 2003;33:270-7.

[36] Yong SD. Culture method of Cordyceps militaris in medium including chitosan. Korea Patent KR20020003485; 2002.

[37] Deok YB. Liquid cultivation method of Cordyceps sinensis. Korea Patent KR20020087193; 2002.

[38] Duck KS. Cordyceps sinensis mycelium and culture method therof. Korea Patent KR20030067209; 2003.

[39] Park JP, Kim SW, Hwang HJ, Cho YJ, Yun JW. Stimulatory effect of plant oils and fatty acids on the exo-biopolymer production in Cordyceps militaris. Enzyme Microbial Technol 2002;31:250-5.

[40] Chen JW, Chen HZ. A preliminary report on solid-state fermentation of Ganoderma lucidum with Radix Astragali containing medium. J Chin Integr Med 2004;2:216-8.

[41] Sheen LY, Wu CC, Lii CK, Tsai SJ. Effect of diallyl sulfide and diallyl disulfide, the active principles of garlic, on the aflatoxin B1-induced DNA damage in primary rat hepatocytes. Toxicol Lett 2001;122: $45-52$.

[42] Xiao JH, Chen DX, Liu JW, Liu ZL, Wan WH, Fang N, et al. Optimization of submerged culture requirements for the production of mycelial growth and exopolysaccharide by Cordyceps jiangxiensis JXPJ 0109. J Appl Microbiol 2004;96:1105-16.

[43] Park JP, Kim SW, Hwang HJ, Yun JW. Optimization of submerged culture conditions for the mycelial growth and exo-biopolymer production by Cordyceps militaris. Lett Appl Microbiol 2001;33: 76-81.

[44] Kim SW, Hwang HJ, Xu CP, Sung JM, Choi JW, Yun JW. Optimization of submerged culture process for the production of mycelial biomass and exo-polysaccharides by Cordyceps militaris C738. J Appl Microbiol 2003;94:120-6.

[45] Wu JY, Zhang QX, Leung PH. Inhibitory effects of ethyl acetate of Cordyceps sinensis mycelium on various cancer cells in culture and B16 melanoma in C57BL/6 mice. Phytomedicine 2007;14:43-9.

[46] Park JP, Kim YM, Kim SW, Hwang HJ, Cho YJ, Lee YS, et al. Effect of aeration rate on mycelial morphology and exo-biopolymer production in Cordyceps militaris. Process Biochem 2002;37:1257-62.

[47] Masuda M, Urabe E, Sakurai A, Sakakibara M. Production of cordycepin by surface culture using the medicinal mushroom Cordyceps militaris. Enzyme Microbial Technol 2006;39:641-6.

[48] Mao XB, Eksriwong T, Chauvatcharin S, Zhong JJ. Optimization of carbon source and carbon/nitrogen ratio for cordycepin production by submerged cultivation of medicinal mushroom Cordyceps militaris. Process Biochem 2005;40:1667-72. 